\title{
Ability grouping in the secondary school: attitudes of teachers of practically based subjects
}

Susan Hallam, Institute of Education, University of London

Lynne Rogers, Open University

Judith Ireson, Institute of Education, University of London

Contact: Professor Susan Hallam, Institute of Education, University of London, 20

Bedford Way, London, WC1H OAA

E-mail s.hallam@ioe.ac.uk

Telephone 02076126371 


\section{Ability grouping in the secondary school: attitudes of teachers of practically based subjects}

\section{Summary}

This research aimed to explore the attitudes of teachers of practically based subjects (arts and sports) towards ability grouping. Teachers from 45 secondary schools adopting different levels of ability grouping completed a questionnaire which elicited their responses to statements of beliefs about ability grouping and its effects. Overall, the physical education teachers exhibited the most positive attitudes towards ability grouping, drama teachers the least, with the music and art teachers in between. The best predictor of teachers' attitudes was the subject that they taught. These findings support the notion that, overall, teachers of practical subjects have positive attitudes towards mixed ability teaching. 


\section{Ability grouping in the secondary school: attitudes of teachers of practically based subjects}

\section{Introduction}

Historically, in the United Kingdom (UK), the secondary education system has largely been based on ability grouping, either between or within schools. Underlying such structured grouping policies are fundamental assumptions relating to the nature of intelligence - broadly, that pupils have different levels of ability which are relatively immutable and unchanging. Despite a growing body of research which challenges these ideas stressing the importance of experience and prior knowledge in human development indicating that what is conceptualised as intelligence is learned, policy makers in the UK have continued to promote the grouping of pupils by 'ability', despite the evidence that structured ability grouping, of itself, does not lead to consistently better or worse attainment for any particular group of pupils and can have negative effects on the personal and social outcomes for particular groups of children (for reviews see Hallam, 2002, Ireson and Hallam, 2001; Sukhnandan and Lee, 1998; Harlen and Malcolm, 1997). Most secondary schools in the UK adopt some form of structured ability grouping, usually setting (pupils being put into ability groups for specific subjects), for at least some subjects (Benn and Chitty, 1996).

A further explanation for the continued adoption of ability grouping structures, despite the evidence indicating their disadvantages, may be the beliefs that teachers hold about ability grouping. Studies of teachers' attitudes towards structured ability grouping in the USA (NEA, 1968; McDermott, 1976; Wilson \& Schmidts, 1978), Sweden (Husen and Boalt, 1967), the UK, (Daniels, 1961a, 1961b; Jackson, 1964, Barker-Lunn, 1970) and Israel (Ministry of Education, 1965; Guttman et al, 1972) have 
revealed that teachers generally hold positive attitudes towards teaching classes where pupils are grouped by ability, although variations have been reported based on teachers' prior experience and the subject that they teach. When mixed-ability teaching was innovatory in the UK, teachers who had direct experience of it tended to hold more favourable attitudes towards it (Newbold, 1977; Reid et al, 1982), although there were differences depending on the subject that they taught. Reid et al. (1982) found that where subjects were structured in such a way that learning built on previous knowledge, for example in mathematics and modern foreign languages, teachers seemed to favour structured ability grouping, while the humanities were perceived as particularly suitable for mixed ability teaching. Ninety percent of language teachers were sceptical of the possibility of effective mixed ability teaching. Scientists occupied a middle position perceiving some difficulties. Those subjects where mixed ability teaching was perceived as problematic tended to require correct answers and a grasp of abstract concepts.

More recent research demonstrated that the best predictor of teachers' attitudes towards and beliefs about structured ability grouping was the dominant grouping in the school where they worked, mixed ability, partially set or set, (standardised beta weight .225) (Hallam and Ireson, 2003). Teachers tended to favour the structured grouping practices adopted in their school. They perceived the advantages of mixed ability teaching largely in social terms, while the disadvantage was perceived to be the difficulty of providing appropriate work for pupils of high and low ability in the same class. Those critical of mixed-ability teaching suggested that it failed to motivate and increase the achievement of the highly able, although the less able were perceived to benefit. The research also found differences in teachers' attitudes towards mixed ability teaching depending on the subject that they taught. Supporting the earlier findings, teachers of mathematics and modern foreign languages tended to hold the most 
positive attitudes, while those teaching English, the humanities, and the arts held the most negative.

Teachers' beliefs about teaching different ability groups affect their expectations of students and the way that they teach (Barker-Lunn, 1970; Hallam and Ireson, 2005) and their interactions with students. Their attitudes can contribute to the alienation of pupils in low ability groups. Pupils from high ability groups tend to exhibit pro-social behaviour and it is this, rather than their academic achievement, which seems to shape teachers' behaviour towards them (Hargreaves, 1967; Lacey, 1970; Ball, 1981; Finley, 1984). Teachers interact with high ability groups more frequently and positively than they do with low ability groups (Harlen and Malcolm, 1997; Sorenson and Hallinan, 1986; Gamoran and Berends, 1987). However, in some schools, presumably where the ethos is supportive of pupils of all abilities, there is evidence that teachers of low stream students do view them positively (Burgess, 1983, 1984).

This paper seeks to further explore these issues in relation to subjects which are practically based i.e. art, music, drama and PE. In these subjects learning outcomes, generally, are not based on written materials. Alternative means of assessment are adopted which may involve active performance or the presentation of a portfolio of work. Previous research into ability grouping has tended not to consider these subjects separately. Art, music and drama have tended to be grouped together as 'the arts' and Physical Education (PE) has generally not been included in the research. In schools these subjects are rarely grouped by ability and where they are taught in ability groups those groups are usually based on classifications derived from more 'academic' subject groupings. While previous research has tended to suggest that teachers of the arts favour mixed ability groupings, a weakness has been that their attitudes have been assessed collectively not taking account of possible differences. This research 
addresses this issue. It is particularly important currently because of the UK government's commitment to encouraging students to engage more fully with the arts and participate in more physical activity. Pupil motivation to do so will be affected by their relationships with teachers, which are in part determined by teachers' beliefs and attitudes, which in turn are influenced by the grouping structures adopted in the school where they teach and the subject that they teach.

\section{Methodology}

A sample of 45 mixed gender secondary comprehensive schools selected from all schools in England participated in the study, to represent a range of grouping practices, intake and location. All schools had received satisfactory inspection reports during the three years before the start of the project. Steps were taken to balance the schools across each of the ability grouping types described below in terms of their size and the social mix of their intake, using free school meals as an indicator of social disadvantage. The schools comprised three levels of ability grouping in the lower secondary school (Years 7 to 9), with 15 schools at each level:

'Mixed Ability Schools' predominantly mixed ability classes for all subjects, with setting in no more than two subjects in Year 9.

'Partially Set Schools' setting in no more than two subjects in Year 7, increasing to a maximum of 4 subjects in Year 9.

'Set Schools' streaming, banding or setting in at least four subjects from Year 7.

Teachers of pupils in years 7,8 and 9 completed a questionnaire developed specifically for the research exploring teachers' attitudes towards ability grouping. Teachers were asked to report the current grouping practices adopted for their subject in their school, the extent to which they supported these practices, and what grouping 
practices they would prefer. Teachers responded on a five point rating scale to a series of statements about ability grouping and mixed ability teaching. The statements were devised based on the existing literature and were extensively piloted before use. The statements were grouped into sections relating to able pupils, personal and social educational outcomes, equal opportunities, behaviour, attendance and exclusion, and beliefs about the effects of different grouping structures on teaching. The actual statements used are reported in the sections referring to the findings of the study. For reasons of space they are not repeated here. Open questions were also included which enabled teachers to express their beliefs in their own words.

Cronbach Alpha statistics relating to the internal reliability of the questionnaire were already established based on a sample of over 1500 teachers representing all subjects. The Cronbach Alpha statistics for each section were: able pupils 0.74; personal and social educational outcomes 0.74 ; equal opportunities 0.67 ; behaviour 0.68 ; attendance at and exclusion from school 0.71 ; and beliefs about the effects of different grouping structures on teaching 0.53. Reliability for the scale as a whole was 0.65 .

This paper focuses on the responses of teachers of art, music, drama and PE. The questionnaires were completed in after school meetings which the teachers attended voluntarily. Data were collected from 72 art teachers, 43 music teachers, 33 drama teachers and 97 PE teachers. There were 144 female teachers and 89 male teachers aged from 20 to $65.32 \%$ were aged from $20-29,24 \%$ from 30 to $39,29 \%$ from 40 to 49 and $11 \%$ over 50.

\section{Findings}


Teachers were asked if they thought that their subject was suitable for mixed ability teaching. $94 \%$ of the drama teachers agreed that it was, $3 \%$ disagreed; $89 \%$ of art teachers agreed, $4 \%$ disagreed; $84 \%$ of the music teachers agreed, $12 \%$ disagreed; and $83 \%$ of the PE teachers agreed and $16 \%$ disagreed. The remainder failed to respond. These differences were not statistically significant.

\section{Current grouping practices and preferred grouping practices}

Most of the classes which the teachers taught were mixed ability. In art 92\%, music $86 \%$, drama $80 \%$ and PE 58\%. In PE, mixed ability grouping in year 7 followed by some kind of setting in years 8 and 9 was prevalent in $14 \%$ of cases. For the remaining teachers a range of practices were in operation including setting (where pupils are grouped according to attainment for each subject) and banding (where pupils are grouped broadly in bands in terms of general attainment and may also be in sets for particular subjects). There were no statistically significant differences in the way that the pupils were grouped in each of the three types of school (set, partially set, mixed ability) in year 7 for these practical subjects, but in years 8 and 9 the schools which overall adopted high levels of setting had statistically significantly higher levels of ability grouping in the practical subjects than the mixed ability or partially set schools.

When asked if they had any reservations about the grouping practices adopted in their schools there were no statistically significant differences between the teachers of the different disciplines (see Table 1). Overall, most teachers had no or only small reservations about the practices adopted in their school, although $70 \%$ of music 
teachers, the group with the highest levels of concern regarding grouping practices, reported having at least a few reservations about current practices. There were no statistically significant differences in responses between teachers from the three types of school.

\section{Table 1 about here}

When teachers were asked what they would like the grouping structures to be mixed ability was still the overwhelming preference (see Table 2), although in music $21 \%$ of teachers indicated that they would like to see setting in years 7,8 , and 9 and $22 \%$ of PE teachers indicated that they would like to see setting in years 8 and 9 and $9 \%$ in years 7,8 and 9 . There were no statistically significant differences between teachers from the three types of schools.

\section{Table 2 about here}

\section{Beliefs about the effects of ability grouping on able pupils}

Mean scores of teachers' responses to a range of statements about ability grouping were calculated for each subject area. Table 3 outlines responses to statements regarding the effects of mixed ability and setting on children whose attainment was above average. Strong agreement with a statement was indicated by a score of 5. The strongest support for setting came from the teachers of PE, the weakest from the drama teachers (see Table 3 for details). The music teachers most strongly agreed that setting prevented brighter children being inhibited by negative peer pressure. The PE and music teachers agreed equally strongly that the bright children were neglected or held back in mixed ability classes. The only statistically significant difference related to the statement that 
setting ensured that the brighter children made maximum progress where the PE teachers most strongly agreed followed by the music teachers. The drama teachers most strongly disagreed with this statement.

\section{Table 3 about here}

\section{Beliefs about the personal and social educational outcomes for pupils}

When the focus of the statements was pupils' personal and social development, the pattern of responses was similar to that for beliefs about the impact on able pupils, i.e. structured ability groupings were seen to favour the more able children. Table 3 gives the means and statistical significance of differences. The teachers most strongly indicating that ability grouping had little impact on personal and social education outcomes were the PE teachers.

\section{Equity issues}

Table 3 illustrates the responses given in relation to the equity of opportunity afforded different groups of children within different grouping structures. There were no statistically significant differences in relation to a range of statements relating to the equity of ability grouping except in relation to mixed ability classes providing the less able with role models of achievement (see Table 3 for details). The drama teachers agreed with this statement significantly more strongly than the other teachers. The music teachers agreed with this statement significantly less strongly.

Behaviour, attendance at and exclusion from school 
In response to statements relating to behaviour and discipline there was close agreement between the teachers of the different subjects. Overall, they disagreed that there were more discipline problems in mixed ability classes and that there were more exclusions from the lower sets. However, they differed in their responses to questions about truancy. The music and art teachers more strongly agreed that truancy was greater in pupils in the lower sets. This was statistically significant (see Table 3 for details).

\section{Ease of teaching ability grouped classes}

When teachers were asked to agree or disagree with statements relating to the ease of teaching in ability grouped classes, there were few significant differences in response. All of the teachers tended to disagree that only very good teachers could teach mixed ability classes successfully and that in mixed ability classes teachers tend to teach to the average child. Overall, there were neutral responses to the statements that setting made classroom management easier and that teaching was easier when classes were set. There was a tendency for all the teachers to agree that developing the appropriate teaching skills necessary to teach a mixed ability class benefited all pupils in the class. There were statistically significant differences between subject specialisms in relation to the statement that setting led to teachers ignoring the fact that a class always contained a range of abilities. The drama teachers most strongly agreed with this statement, the PE teachers most strongly disagreed. The PE teachers most strongly agreed that setting enabled pupils' curriculum needs to be better matched while the drama teachers most strongly disagreed. These differences were statistically significant (see Table 4 for details). Music teachers responses fell between the extremes in relation to all of these statements.

\section{Table 4 about here}

\section{Factor analysis}


A factor analysis was undertaken using principal components analysis and varimax rotation. The scree plot revealed that a three factor solution was the most parsimonious. This solution accounted for $47 \%$ of the variance. The eigenvalues of the three factors were $6.86,2.86$ and 1.49 respectively.

Table 5 sets out the weightings for each statement for each factor. Factor 1 has high weightings for statements supporting mixed ability teaching including those relating to equity issues, and the motivation, and personal and social adjustment of all pupils. The key focus is the benefit of mixed ability teaching to all pupils and the negative aspects of structured ability grouping for some. Factor 2 has high weightings on responses to statements supporting structured ability grouping including those relating to the ease of teaching, classroom management, matching the curriculum to student needs and the benefits to able children. Factor 3 has high loadings on issues relating to truancy, exclusion, discipline and the lack of motivation of pupils in lower ability groups (see Table 5).

\section{Table 5 about here}

Comparison of the scores of the teachers of each subject on each factor indicated no significant differences in responses to the second factor. However, there were statistically significant differences between the PE and drama teachers in relation to Factor 1 , the means being PE .21 , drama -.37 , music -.17 , and art $-.06(\mathrm{~F}=3.33$, df $=$ 3,194. $\mathrm{p}=.021)$ and for PE and all of the other teachers on Factor 3, the means being PE .29, drama -.34 , music -.19 , and art $-.2(\mathrm{~F}=5.19$, df $=3,194 . \mathrm{p}=.002)$. The PE teachers scores loaded positively on this factor in contrast to the other teachers where the loadings were negative. This suggests that the PE teachers in the sample were more sensitive than the art, music and drama teachers to issues relating to the lower ability pupils' behaviour, motivation and attendance. 


\section{Overall attitudes to ability grouping}

An overall attitude to setting scale was created by summing responses to the attitudinal statements described above. Where necessary numerical responses were reversed so that all responses were in a similar direction. A high score indicated a positive attitude towards structured ability grouping. The most positive attitudes to ability grouping were exhibited by the PE teachers followed by the music and art teachers. Those with the least positive attitudes were the drama teachers (see table 6). These differences were highly significant statistically $(\mathrm{F}=6.35, \mathrm{df}=3,190, \mathrm{p}=.0001)$ and appeared between all groups of subject teachers except those of music with drama and art. These findings mirrored those reported earlier regarding which subjects were considered suitable for mixed ability teaching. Teachers with the most positive attitudes towards ability grouping reported that their subject was least suitable for mixed ability teaching.

\section{Table 6 about here}

Multiple regression undertaken to demonstrate the best predictor of attitudes towards ability grouping demonstrated that of age, gender, subject specialism and type of school (set, partially set and mixed ability) the best and only significant predictor was the subject taught (beta $=.170, \mathrm{~F}=5.68, \mathrm{df}=1,192, \mathrm{p}=.018$ ).

\section{Rationale for responses}

The open questions provided insights into why the teachers responded as they did. Reasons given for difficulties with structured ability grouping included those relating to the nature of the practical subjects which differed from academic subjects in what was required of pupils: 
'The nature of a mainly practical subject does not necessarily need academic setting'. (music teacher)

Where the school adopted setting procedures a major problem for teachers of the arts and PE was that the grouping practices tended to be based on performance in academic subjects:

'The criteria which assess 'academic' ability (numeracy, literacy) whilst a good indication of general art ability (i.e. the higher the better) do not indicate particular or specific ability in art.' (art teacher)

Similarly, carousel arrangements for timetabling based on academically setted groups were viewed as problematic:

'All pupils are different. They mature at different speeds, learn at different speeds and work at different speeds no matter what the subject. Therefore if you are going to set pupils for one subject there needs to be consistency, because a pupil may excel at music but may not be so good at technology.' (music teacher)

There were some teachers who indicated that they would prefer pupils to be ability grouped for their subject:

'I would prefer setting specifically for PE as ability is not necessarily consistent across the curriculum.' (PE teacher) 
'Setting is best to enable more successful teaching and learning. I don't believe that mixed ability teaching works as well as other methods.' (music teacher).

If structured ability grouping was to be adopted teachers indicated that it was important to establish current skill levels before allocating pupils to groups:

'In year 7 we don't know children's ability until they arrive. During years 7 and 8 children's keyboard skills change according to effort or ability. In year 9 many are disaffected so written work and reading ability does not always match up with practical musical ability so I would prefer setting in year 9.' (music teacher)

A number of teachers commented on the different sizes of ability grouped classes:

Middle ability groups are very much larger than lower ability groups (PE teacher)

These differences in class size influenced the nature of the teaching:

'In PE the lower sets are smaller and you can give them more time. It is a subject where you display your talents and I believe the lower set pupils feel more comfortable and develop skills without inhibition.' (PE teacher)

\section{Discussion}

Overall, the teachers of these practically based subjects supported mixed ability teaching. Only a small proportion of teachers believed that some form of ability grouping would be beneficial. Surprisingly, the largest group in this respect was the PE teachers with $32 \%$ indicating that they would prefer some form of ability grouping 
after year 7. In music, $49 \%$ of teachers preferred to have classes in mixed ability groups in years 7,8 and 9 , while at the other extreme, $21 \%$ indicated that they preferred pupils to be setted in all three year groups. In drama and art intermediate levels of structured grouping or other alternative strategies were preferred.

Further research needs to be undertaken to consider the reasons for these differences. As in any study based on likert scale responses to questionnaire statements there are limitations on the respondents' ability to express their own views. One of the striking features of much of the data reported here is the lack of strong agreement with any of the statements. While, overall, the teachers favoured mixed ability teaching, their attitudes towards it and beliefs about its impact based on their responses to these statements were not strong. Perhaps the way that pupils are grouped between classes is not an important issue for teachers of practical subjects and that within class groupings are more salient. Perhaps teachers of PE and music where children frequently have to work together in within class groupings prefer those groups to be of similar levels of expertise. The PE teachers most strongly agreed that setting ensured that the brighter children made maximum progress suggesting that in some sports there are perceived advantages in having those who are physically more able working together. Certainly they most strongly disagreed that motivation was higher when pupils were in mixed ability classes and that knowing that they were in a low set led pupils to give up. They also most strongly disagreed that mixed ability classes led to better social adjustment. Perhaps in PE where shortcomings are very obvious those with less expertise tend to try harder when their efforts are not compared with the more able. In addition, there may be some issues of boys and girls having to be taught PE together when there are sometimes marked differences in physical strength. In music where group composition and performance are common activities teachers may feel that the work of the whole group is held back if some members have fewer 
musical skills. In team sports and music children not only work together but hold collective responsibility for a learning outcome. This may also be an important factor influencing teachers' attitudes. Why the drama teachers, who also engage the children in considerable group work do not share these views is interesting. Perhaps they perceive the aims of drama education in a different light - being more concerned with process and progression than outcomes. In contrast, in art, work tends to be undertaken at the individual level creating less potential for interference with progress from others.

Where setting was implemented in the school, it was often based on academic attainment so that pupils were often at very different levels of expertise in the arts and PE. For some teachers this was a source of frustration. School procedures seemed to reflect a lack of value attached to their subject in comparison with more academic subjects and they wanted setting to be undertaken in relation to their subject. Teachers may also have felt that grouping pupils by ability in their classes may have encouraged more pupils to take their subjects when entered for the General Certificate of Secondary Education (GCSE). In considering the way that students are grouped structurally within schools, managers should take account of the impact on the teaching of practical subjects and avoid making grouping decisions based only on the perceived needs of academic subjects.

An earlier study, which included data from all school subjects, showed a significant relationship between the type of ability grouping practices adopted in the whole school (set, mixed ability, partially set) on teachers' attitudes towards and beliefs about ability grouping (Hallam and Ireson, 2003). This was not the case in the current sample suggesting that irrespective of school ethos, teachers of the arts and PE, overall, hold fairly similar views about grouping practices. The relatively low 
standard deviations for the overall attitude and belief scores, particularly for music and PE teachers, support this view. This may be because arts and PE teachers are relatively isolated from other school staff, in part because they may be the sole full time representative of their subject and also because at lunchtimes and after school they may be engaged in a range of extra-curricula activities rather than engaging in exchanges with other school staff.

Whatever the nature of the grouping practices adopted, teachers' beliefs about the nature of their subject influence the way that they teach (Barker-Lunn, 1970; Hallam and Ireson, 2005). Where school grouping practices do not fit well with their beliefs about pedagogy teachers may compensate within the classroom. In planning grouping structures, school managers may find it productive to acknowledge and take account of these subject differences, facilitating the pedagogy which teachers believe to be most appropriate.

\section{Acknowledgements}

This research was supported by funding from the Economic and Social Research Council. The authors would like to thank Sarah Hack and Helen Clark the researchers on the project for their careful collection of data and to the participating schools for giving of their time.

\section{References}

Barker Lunn, J.C. (1970) Streaming in the Primary School. (Slough, NFER) 
Ball, S.J. (1981) Beachside Comprehensive: A case-study of secondary schooling. (Cambridge, Cambridge University Press)

Burgess, R.G. (1983) Experiencing comprehensive education: A study of Biship McGregor School. (London: Methuen)

Burgess, R.G. (1984) It's not a proper subject: It's just Newsom In I. Goodson \& S. Ball (eds) Defining the curriculum (London: Falmer).

Daniels, J.C. (1961) The effects of streaming in the primary schools: I What teachers believe. British Journal of Educational Psychology, 31, 69-78

Finley, M.K (1984) Teachers and tracking in a comprehensive high school. Sociology of Education, 57, 233-243.

Gamoran, A. \& Berends, M. (1987) The effects of stratification in secondary schools: Synthesis of survey and ethnographic research. Review of Educational Research, 57, $415-435$

Guttman, Y., Gur, A., Daniel, S., \& Well, D. (1972) The effects of ability grouping on learning achievements and psychosocial development. (Jerusalem, Szold Institute)

Hallam, S. (2002) Ability Grouping in Schools: a Literature Review. (Institute of Education, University of London)

Hallam, S. \& Ireson, J. (2003) Secondary School Teachers' Attitudes to and Beliefs about Ability Grouping, British Journal of Educational Psychology, 73, 343-356. 
Hallam, S. \& Ireson, J. (2005) Secondary School Teachers' Pedagogic Practices when Teaching Mixed and Structured Ability Classes, Research Papers in Education, 20 (1), 3-24.

Hargreaves, D.H. (1967) Social relations in a Secondary school. (London: Tinling).

Harlen, W. \& Malcolm, H. (1997) Setting and streaming: a research review (Using Research Series 18). (Edinburgh, SCRE)

Husen, T., \& Boalt, G. (1967) Educational research and educational change: The case of Sweden. (Stockholm, Almquist)

Ireson, J. \& Hallam, S. (1999) Raising standards: is ability grouping the answer? Oxford Review of Education, 25(3), 343-358.

Ireson, J. \& Hallam, S. (2001) Ability Grouping in Education. (London, Sage)

Jackson, B. (1964) Streaming: An education system in miniature. (London, Routledge \& Kegan Paul)

Lacey, C. (1970) Hightown Grammar. ( Manchester: Manchester University Press)

Mcdermott, J.W. (1976) The controversy over ability grouping in American education, 1916-1970 Doctoral dissertation, Temple University, Philadelphia, Xerox: University Microfilms. 
Ministry Of Education (Israel). (1965) Survey of grouping. (Jerusalem, The pedagogic secretariat (Hebrew))

NEA (1968) Ability grouping: Research summary. (Washington, National Education Association)

Newbold, D. (1977) Ability grouping: the Banbury Enquiry. (Slough, National Foundation for Educational Research Publishing Company Ltd)

Reid, M.E., Clunies-Ross, L.R., Goacher, B., \& Vile, D. (1982) Mixed ability teaching: Problems and possibilities. (Windsor, NFER-Nelson)

Sorenson, A.B. and Hallinan, M.T. (1986) Effects of ability grouping on growth in academic achievement, American Educational Research Journal, 23(4), 519-42.

Sukhnandan, L., \& Lee, B. (1998) Streaming, setting and grouping by ability. (Slough, National Foundation for Educational Research)

Wilson, B.J. \& Schmidts, D.W. (1978) What's new in ability grouping? Phi Delta Kappan, 59, 535-536. 
Table 1: Teachers' attitudes towards the grouping practices adopted in their schools

\begin{tabular}{|l|l|l|l|l|}
\hline & $\begin{array}{l}\text { I have no } \\
\text { reservations } \\
\text { about the } \\
\text { current } \\
\text { practices }\end{array}$ & $\begin{array}{l}\text { I have a few } \\
\text { reservations } \\
\text { about the } \\
\text { current } \\
\text { practices }\end{array}$ & $\begin{array}{l}\text { I have quite } \\
\text { a lot of } \\
\text { reservations } \\
\text { about the } \\
\text { current } \\
\text { practices }\end{array}$ & $\begin{array}{l}\text { I am very } \\
\text { opposed to } \\
\text { many of the } \\
\text { current } \\
\text { practices }\end{array}$ \\
\hline Art & $47 \%$ & $40 \%$ & $10 \%$ & $1 \%$ \\
\hline Music & $30 \%$ & $56 \%$ & $9 \%$ & $5 \%$ \\
\hline Drama & $52 \%$ & $33 \%$ & $9 \%$ & $3 \%$ \\
\hline Physical Education & $58 \%$ & $30 \%$ & $7 \%$ & $3 \%$ \\
\hline
\end{tabular}


Table 2: Preferences for grouping practices

\begin{tabular}{|l|l|l|l|l|}
\hline $\begin{array}{l}\text { Preferred grouping practices in } \\
\text { years 7, 8 and 9 }\end{array}$ & Art & Music & Drama & $\begin{array}{l}\text { Physical } \\
\text { education }\end{array}$ \\
\hline MA MA MA & $68 \%$ & $49 \%$ & $67 \%$ & $40 \%$ \\
\hline MA MA ST & $13 \%$ & $7 \%$ & $6 \%$ & $6 \%$ \\
\hline MA MA O & $1 \%$ & & $6 \%$ & $2 \%$ \\
\hline MA ST ST & $4 \%$ & $5 \%$ & & $22 \%$ \\
\hline ST ST ST & $6 \%$ & $21 \%$ & & $9 \%$ \\
\hline BM BM BM & & $7 \%$ & & $1 \%$ \\
\hline Other & $8 \%$ & $11 \%$ & $21 \%$ & $20 \%$ \\
\hline
\end{tabular}

$\mathrm{MA}=$ mixed ability, $\mathrm{ST}=$ setting, $\mathrm{O}=$ other, $\mathrm{BM}=$ banding 
Table 3: Subject teachers' beliefs about the effects of ability grouping on able pupils, personal and social educational outcomes, equal opportunities and behaviour

\begin{tabular}{|c|c|c|c|c|c|}
\hline Statements & Art & Music & Drama & PE & Sig \\
\hline \multicolumn{6}{|l|}{ Able pupils } \\
\hline $\begin{array}{l}\text { Bright children are neglected or held back in mixed ability } \\
\text { classes }\end{array}$ & $\begin{array}{l}1.82 \\
(1.29)\end{array}$ & $\begin{array}{l}2.14 \\
(1.08)\end{array}$ & $\begin{array}{l}2.03 \\
(1.05)\end{array}$ & $\begin{array}{l}2.14 \\
(1.1)\end{array}$ & NS \\
\hline $\begin{array}{l}\text { Setting ensures that brighter children make maximum } \\
\text { progress }\end{array}$ & $\begin{array}{l}2.53 \\
(.88)\end{array}$ & $\begin{array}{l}2.72 \\
(.91)\end{array}$ & $\begin{array}{l}2.39 \\
(1.25)\end{array}$ & $\begin{array}{l}2.93 \\
(.82)\end{array}$ & .008 \\
\hline $\begin{array}{l}\text { Setting prevents brighter children being inhibited by } \\
\text { negative peer pressure }\end{array}$ & $\begin{array}{l}2.5 \\
(1.03)\end{array}$ & $\begin{array}{l}2.58 \\
(.82)\end{array}$ & $\begin{array}{l}2.12 \\
(1.1)\end{array}$ & $\begin{array}{l}2.48 \\
(.99)\end{array}$ & NS \\
\hline Statements & Art & Music & Drama & $\mathbf{P E}$ & Sig \\
\hline \multicolumn{6}{|l|}{ Personal and social educational outcomes } \\
\hline $\begin{array}{l}\text { Setting has a damaging effect on the self-esteem of those } \\
\text { in lower sets }\end{array}$ & $\begin{array}{l}2.56 \\
(1.04)\end{array}$ & $\begin{array}{l}2.41 \\
(.95)\end{array}$ & $\begin{array}{l}2.7 \\
(1.19)\end{array}$ & $\begin{array}{l}2.15 \\
(1.06)\end{array}$ & .027 \\
\hline Setting children stigmatises those perceived as less able & $\begin{array}{l}2.51 \\
(1.08) \\
\end{array}$ & $\begin{array}{l}2.79 \\
(.91)\end{array}$ & $\begin{array}{l}2.58 \\
(1.3)\end{array}$ & $\begin{array}{l}2.31 \\
(1.07\end{array}$ & NS \\
\hline $\begin{array}{l}\text { Less able children compare themselves unfavourably to } \\
\text { more able children in mixed ability classes }\end{array}$ & $\begin{array}{l}2 \\
(1.06)\end{array}$ & $\begin{array}{l}2.21 \\
(1.0)\end{array}$ & $\begin{array}{l}1.88 \\
(1.08)\end{array}$ & $\begin{array}{l}2.21 \\
(.89)\end{array}$ & NS \\
\hline $\begin{array}{l}\text { Mixed ability grouping leads to better social adjustment } \\
\text { for the less able pupils }\end{array}$ & $\begin{array}{l}2.74 \\
(.85)\end{array}$ & $\begin{array}{l}2.58 \\
(.82)\end{array}$ & $\begin{array}{l}2.91 \\
(.93)\end{array}$ & $\begin{array}{l}2.43 \\
(.89)\end{array}$ & .024 \\
\hline $\begin{array}{l}\text { Mixed ability grouping leads to better social adjustment } \\
\text { of all pupils }\end{array}$ & $\begin{array}{l}2.76 \\
(.89)\end{array}$ & $\begin{array}{l}2.55 \\
(.74)\end{array}$ & $\begin{array}{l}2.73 \\
(1.1)\end{array}$ & $\begin{array}{l}2.2 \\
(.89)\end{array}$ & .0001 \\
\hline $\begin{array}{l}\text { Overall, motivation is higher when pupils are in mixed } \\
\text { ability classes }\end{array}$ & $\begin{array}{l}2.01 \\
(1.02)\end{array}$ & $\begin{array}{l}2 \\
(.87)\end{array}$ & $\begin{array}{l}2.27 \\
(.91)\end{array}$ & $\begin{array}{l}1.67 \\
(.89)\end{array}$ & .006 \\
\hline Knowing they are in a low set leads to pupils giving up & $\begin{array}{l}2.44 \\
(1.07)\end{array}$ & $\begin{array}{l}2.22 \\
(.99)\end{array}$ & $\begin{array}{l}2.67 \\
(1.08)\end{array}$ & $\begin{array}{l}1.76 \\
(1.02)\end{array}$ & .0001 \\
\hline Statements & Art & Music & Drama & PE & Sig \\
\hline \multicolumn{6}{|l|}{ Equal opportunities } \\
\hline $\begin{array}{l}\text { Setting benefits the more able pupils at the expense of the } \\
\text { less able }\end{array}$ & $\begin{array}{l}1.84 \\
(1.24)\end{array}$ & $\begin{array}{l}1.71 \\
(1.11)\end{array}$ & $\begin{array}{l}2.03 \\
(1.24)\end{array}$ & $\begin{array}{l}1.32 \\
(1.08)\end{array}$ & .005 \\
\hline Mixed ability grouping gives each child a fair chance & $\begin{array}{l}2.07 \\
(.99)\end{array}$ & $\begin{array}{l}1.86 \\
(1.03)\end{array}$ & $\begin{array}{l}2 \\
(1.09) \\
\end{array}$ & $\begin{array}{l}1.67 \\
(1.04)\end{array}$ & NS \\
\hline $\begin{array}{l}\text { Mixed ability classes provide the less able pupils with } \\
\text { positive models of achievement }\end{array}$ & $\begin{array}{l}2.73 \\
(.79)\end{array}$ & $\begin{array}{l}2.58 \\
(.82)\end{array}$ & $\begin{array}{l}2.81 \\
(.97)\end{array}$ & $\begin{array}{l}2.73 \\
(.79)\end{array}$ & .007 \\
\hline Statements & Art & Music & Drama & PE & Sig \\
\hline \multicolumn{6}{|l|}{ Behaviour } \\
\hline $\begin{array}{l}\text { In general there are more discipline problems in mixed } \\
\text { ability classes }\end{array}$ & $\begin{array}{l}1.67 \\
(1.37)\end{array}$ & $\begin{array}{l}1.79 \\
(1.14)\end{array}$ & $\begin{array}{l}1.61 \\
(1.12)\end{array}$ & $\begin{array}{l}2.09 \\
(1.09)\end{array}$ & NS \\
\hline $\begin{array}{l}\text { Where classes are set there are more discipline problems } \\
\text { in the lower ability classes }\end{array}$ & $\begin{array}{l}2.63 \\
(1.11)\end{array}$ & $\begin{array}{l}2.54 \\
(1.14)\end{array}$ & $\begin{array}{l}2.76 \\
(1.03)\end{array}$ & $\begin{array}{l}2.27 \\
1.19) \\
\end{array}$ & NS \\
\hline Attendance and exclusion & Art & Music & Drama & $\mathbf{P E}$ & \\
\hline $\begin{array}{l}\text { Where classes are set there is more truancy from pupils in } \\
\text { the lower sets }\end{array}$ & $\begin{array}{l}2.05 \\
(.78)\end{array}$ & $\begin{array}{l}2.06 \\
(.64)\end{array}$ & $\begin{array}{l}2 \\
(.66)\end{array}$ & $\begin{array}{l}1.71 \\
(.97)\end{array}$ & .036 \\
\hline $\begin{array}{l}\text { Where classes are set there are more exclusions of pupils } \\
\text { in the lower sets }\end{array}$ & $\begin{array}{l}2.08 \\
(.87)\end{array}$ & $\begin{array}{l}2.18 \\
(.73)\end{array}$ & $\begin{array}{l}2.27 \\
(.67)\end{array}$ & $\begin{array}{l}1.91 \\
.91)\end{array}$ & NS \\
\hline
\end{tabular}

* Figures in brackets are standard deviations 
Table 4: Subject teachers' beliefs about the effects of different grouping structures on teaching

\begin{tabular}{|l|l|l|l|l|l|}
\hline Statements & Art & Music & Drama & PE & Sig \\
\hline $\begin{array}{l}\text { Setting leads to teachers ignoring the fact } \\
\text { that a class always contains a range of } \\
\text { abilities }\end{array}$ & $\begin{array}{l}1.81 \\
(1.04)\end{array}$ & $\begin{array}{l}1.79 \\
(1.0)\end{array}$ & $\begin{array}{l}2 \\
(1.06)\end{array}$ & $\begin{array}{l}1.51 \\
(.97)\end{array}$ & .039 \\
\hline $\begin{array}{l}\text { Only very good teachers can teach mixed } \\
\text { ability classes successfully }\end{array}$ & $\begin{array}{l}1.87 \\
(1.12)\end{array}$ & $\begin{array}{l}1.83 \\
(.91)\end{array}$ & $\begin{array}{l}1.64 \\
(1.19)\end{array}$ & $\begin{array}{l}1.83 \\
(1.2)\end{array}$ & NS \\
\hline Teaching is easier for the teacher when & 2.26 & 2.36 & 2.06 & 2.54 & NS \\
classes are set & $(.99)$ & $(.98)$ & $(1.06)$ & $(.98)$ & \\
\hline In mixed ability classes teachers tend to & 1.86 & 1.93 & 1.82 & 2.2 & NS \\
teach to the average child & $(1.16)$ & $(.91)$ & $(.95)$ & $(.93)$ & \\
\hline Setting makes classroom management & 2.31 & 2.44 & 2.33 & 2.67 & NS \\
easier & $(1.0)$ & $(.91)$ & $(1.05)$ & $(.89)$ & \\
\hline Setting enables pupils' curriculum needs & 2.41 & 2.67 & 2.03 & 2.87 & .0001 \\
to be better matched & $(1.02)$ & $(.97)$ & $(1.05)$ & $(.67)$ & \\
\hline
\end{tabular}

* Figures in brackets are standard deviations 


\begin{tabular}{|c|c|c|c|}
\hline & \multicolumn{3}{|c|}{ Factors } \\
\hline & 1 & 2 & 3 \\
\hline Setting children stigmatises those perceived as less able & .630 & & .285 \\
\hline $\begin{array}{l}\text { Setting benefits the more able pupils at the expense of the less } \\
\text { able }\end{array}$ & .496 & & .414 \\
\hline $\begin{array}{l}\text { In general there are more discipline problems in mixed ability } \\
\text { classes }\end{array}$ & -.515 & .346 & \\
\hline $\begin{array}{l}\text { Setting leads to teachers ignoring the fact that a class always } \\
\text { contains a range of abilities }\end{array}$ & .338 & & .559 \\
\hline Mixed ability grouping gives each child a fair chance & .547 & -.348 & .205 \\
\hline Setting ensures that brighter children make maximum progress & & .496 & -.283 \\
\hline $\begin{array}{l}\text { Overall motivation is higher when pupils are in mixed ability } \\
\text { classes }\end{array}$ & .676 & -.300 & \\
\hline $\begin{array}{l}\text { Where classes are set there are more discipline problems in the } \\
\text { lower ability classes }\end{array}$ & .265 & & .544 \\
\hline $\begin{array}{l}\text { Only very good teachers can teach mixed ability classes } \\
\text { successfully }\end{array}$ & & .469 & .243 \\
\hline $\begin{array}{l}\text { Mixed ability grouping leads to better social adjustment for the } \\
\text { less able pupils }\end{array}$ & .644 & & \\
\hline $\begin{array}{l}\text { Mixed ability classes provide the less able pupils with positive } \\
\text { models of achievement }\end{array}$ & .694 & & .202 \\
\hline $\begin{array}{l}\text { Where classes are set there is more truancy from pupils in the } \\
\text { lower sets }\end{array}$ & & & .787 \\
\hline Teaching is easier for the teacher when classes are set & & .608 & \\
\hline $\begin{array}{l}\text { Less able children compare themselves unfavourably to more } \\
\text { able children in mixed ability classes }\end{array}$ & -.526 & .370 & \\
\hline $\begin{array}{l}\text { Bright children are neglected or held back in mixed ability } \\
\text { classes }\end{array}$ & -.507 & .581 & \\
\hline Where classes are set there are more exclusions in the lower sets & & & .740 \\
\hline $\begin{array}{l}\text { In mixed ability classes teachers tend to teach to the average } \\
\text { child }\end{array}$ & -.419 & .446 & \\
\hline $\begin{array}{l}\text { Mixed ability grouping leads to better social adjustment for all } \\
\text { pupils }\end{array}$ & .742 & & \\
\hline $\begin{array}{l}\text { Setting has a damaging effect on the self-esteem of those in } \\
\text { lower sets }\end{array}$ & .619 & & .351 \\
\hline Setting makes classroom management easier & & .697 & \\
\hline $\begin{array}{l}\text { Teaching the lower sets requires a different approach to teaching } \\
\text { the higher sets }\end{array}$ & & .589 & \\
\hline $\begin{array}{l}\text { Setting prevents brighter children being inhibited by negative } \\
\text { peer pressure }\end{array}$ & -.279 & .591 & \\
\hline Setting enables pupils' curriculum needs to be better matched & -.306 & .656 & -.217 \\
\hline Knowing they are in a low set leads to pupils giving up & .497 & & .558 \\
\hline
\end{tabular}


Table 6: Subject teachers' overall attitudes to ability grouping

\begin{tabular}{|l|l|l|l|l|l|}
\hline Subject & $\begin{array}{l}\text { Number } \\
\text { of } \\
\text { teachers }\end{array}$ & Mean & SD & Minimum & Maximum \\
\hline Art & 49 & 83.4 & 15.85 & 50 & 116 \\
\hline Music & 27 & 83 & 10.17 & 60 & 100 \\
\hline Drama & 31 & 77.58 & 14.07 & 49 & 103 \\
\hline PE & 87 & 88.56 & 10.17 & 62 & 110 \\
\hline
\end{tabular}

